\title{
Pengembangan Media Tumblr Light bagi Pemahaman Konsep Hubungan Antargaris
}

\author{
Ratna Sari Dewi ${ }^{1}{ }^{*}$, Suyitno $^{2}$, Arfilia Wijayanti ${ }^{3}$ \\ ${ }_{123}$ Program Studi Pendidikan Guru Sekolah Dasar, Fakultas Ilmu Pendidikan Universitas PGRI Semarang
}

\begin{abstract}
Abstrak
Latar belakang yang mendorong penelitian ini adalah pemahaman siswa terhadap hubungan antargaris masih rendah, siswa tidak aktif dalam proses pembelajaran karena proses pembelajaran kurang menarik, serta terbatasnya media pembelajaran untuk mata pelajaran Matematika. Rumusan masalah dalam penelitian ini adalah "Bagaimanakah pengembangan media Tumblr Light bagi Pemahaman Konsep Hubungan Antargaris siswa kelas IV Sekolah Dasar?'. Jenis penelitian ini adalah penelitian dan pengembangan (research and development). Penelitian ini dilakukan di SDN 04 Wonokromodi kelas IV. Hasil uji kevalidan diperoleh berdasarkan penilaian dari ahli media sebesar 92,5\% dengan kriteria "sangat baik" dan dari skor rata-rata presentase keidealan ahli materi sebesar 94,1\% dengan kriteria "sangat baik". Sedangkan hasil uji kepraktisan diperoleh berdasarkan penilaian respon guru dan siswa dengan respon guru sebesar $92 \%$ dengan kriteria "sangat baik" dan respon siswa sebesar 95,65\% dengan kriteria "sangat baik". Kesimpulannya bahwa media Tumblr Light valid dan praktis digunakan untuk siswa kelas IV Sekolah Dasar dan dapat digunakan sebagai penyempurna penelitian dan sebagai salah satu alternatif guru dalam mengajar siswa kelas IV Sekolah Dasar.
\end{abstract}

Keywords:

Pengembangan, Tumblr Light, Matematika

\section{PENDAHULUAN}

Menurut Soegeng (2017: 10) "Pendidikan merupakan kegiatan tingkat pertama, yang berkenaan dengan mengajar dang mengembangkan anak muda. Pendidikan itu sendiri merupakan kegiatan tingkat tinggi, yaitu menteorikan pendidikan, pembentukan teori-teori tentang pendidikan". Menurut UndangUndang Republik Indonesia Nomor 20 Tahun 2003 tentang Sistem Pendidikan Nasional:

"Pendidikan adalah usaha sadar dan terencana untuk mewujudkan suasana belajar dan proses pembelajaran agar peserta didik secara aktif mengembangakn potensi dirinya untuk memiliki kukuatan spiritual keagamaan, pengendalian diri, kepribadian, kecerdasan, akhlak mulia, serta keterampilan yang diperlukan dirinya, masyarakat, bangsa dan Negara". "Pendidikan nasional adalah pendidikan yang berdasarkan Pancasila dan Undang-Undang Dasar Negara Republik Indonesia Tahun 1945 yang berakar pada nilai-nilai agama, kebudayaan nasional Indonesia dan tanggap terhadap tuntutan zaman".

Menurut Romadhoni matematika merupakan ilmu tentang bilangan dan berhubungan erat dengan hitung menghitung melalui cara berfikir untuk membuktikan apakah suatu pernyataan benar atau salah dengan menggunakan logika. Misalnya dalam hal jual beli, menghitung laba rugi, mengukur luas lapangan, menghitung jarak, menghitung persen, mengukur besar sudut dan semua hal yang berhubungan dengan membuktikan kebenaran, maka sejauh itulah kita membutuhkan matematika untuk menyelesaikan persoalan tersebut. Pada hakikatnya pembelajaran matematika merupakan proses yang sengaja dirancang dengan tujuan untuk menciptakan suasana lingkungan 
memungkinkan seseorang melaksanakan kegiatan matematika, dan proses tersebut berpusat pada guru mengajar matematika.

Untuk memperoleh hasil yang baik dalam proses pembelajaran maka proses pembelajaran harus ditunjang dengan media yang mendukung karena media pembelajaran merupakan perantara atau pengantar terjadinya komunikasi yang baik dan menyenangkan antara guru dengan peserta didik. Fungsi dari sarana penunjang pendidikan antara lain perpustakaan, laboratorium, alat peraga, media pendidikan, komputer, dll. Salah satu media pendidikan yang dimaksud adalah buku pelajaran yang menjadi sumber belajar bagi siswa. Penggunaan media pembelajaran sangat penting terutama dalam mengajar siswa Sekolah Dasar yang rata-rata berusia 7-11 tahun.

Berdasarkan observasi yang dilakukan dengan guru, yang dilakukan di SDN 04 Wonokromo kelas IV, dalam kegiatan belajar mengajar siswa tidak paham dengan materi matematika pada hubungan antargaris. Selain itu, kurangnya media pembelajaran yang mendukung dalam kegiatan pembelajaran. Siswa juga tidak bersemangat dalam mengikuti pelajaran dikarenakan materi pada pembelajaran matematika dirasa sulit dan membutuhkan pemahaman ekstra serta siswa kurang antusias dalam mengikuti pembelajaran. Banyak faktor yang mempengaruhi hal tersebut diantaranya adalah pembelajaran belum menggunakan media pembelajaran yang menarik dan yang sesuai dengan materi yang menyebabkan kurangnya perhatian siswa untuk semangat belajar.

Dari beberapa temuan di atas, hal itulah yang menyebabkan perlu adanya pengembangan media yang sesuai dengan materi hubungan antargaris. Jika hal tersebut dibiarkan berlarut-larut akan berdampak buruk bagi mutu dan kualitas pembelajaran matematika di Sekolah Dasar, khususnya akan berdampak buruk bagi kemajuan belajar siswa. Dari permasalahan yang timbul maka perlu solusi yang sesuai. Berdasarkan masalah yang ada, maka hendaknya memilih media pembelajaran yang tepat, memberikan penyajian materi yang menarik, serta membuat siswa semangat dalam kegiatan belajar mengajar. Selain itu, media pembelajaran juga mempermudah dalam menyampaikan materi. Dengan mengemas pelajaran yang menarik melalui media pembelajaran akan melatih konsentrasi dan pemahaman siswa. Cenderung siswa menyukai media yang terlihat menarik dan berwarna-warni seperti pemanfaatan lampu yaitu Tumblr Light dalam kegiatan pembelajaran yang akan menjadikan daya tarik bagi siswa sehingga menimbulkan minat siswa dalam mengikuti pembelajaran serta membantu siswa dalam pemahaman terhadap pembelajaran matematika. Hasil penelitian yang dilakukan oleh Eni Yulianti, Zulkardi, dan Rusdy A Siroj (2010) dalam jurnal yang berjudul Pengembangan Media Electric Blood pada Pembelajaran Sistem Peredaran Darah Manusia untuk Siswa Kelas V Sekolah Dasar, didapatkan hasil yang masuk kategori sangat layak serta penelitian yang dilakukan oleh Eni Yulianti, Zulkardi, dan Rusdy A Siroj (2010) dalam penelitian jurnal yang berjudul Pengembangan Alat Peraga Menggunakan Rangkaian Listrik Seri-Pararel untuk Mengajarkan Logika Matematika di SMK Negeri 2 Palembang. Dalam penelitian ini alat peraga tersebut memiliki efek positif terhadap hasil belajar siswa, hal ini terlihat dengan adanya korelasi yang cukup positif antara keaktifan dengan hasil belajar.

Untuk itu mengembangkan media Tumblr Light pada materi Hubungan Antargaris kelas IV Sekolah Dasar pada mata pelajaran Matematika. Media Tumblr Light yang dikembangkan ini mengenai Hubungan Antargaris yang akan didesain secara vertikal dan horisontal sesuai dengan materi Hubungan Antargaris, yaitu garis sejajar, berpotongan, dan berhimpitan. Media Tumblr Light ini diharapkan dapat membantu siswa dalam memahami mata pelajaran Matematika materi Hubungan Antargaris.

Berdasarkan uraian di atas dapat disimpulkan bahwa penggunaan media yang menarik dapat dijadikan suatu media yang inovatif, serta berpengaruh terhadap pemahaman siswa, sehingga tertarik untuk membuat penelitian yang berjudul Pengembangan Media Tumblr Light Bagi Pemahaman Konsep Hubungan Antargaris Siswa Kelas Iv Sekolah Dasar.

\section{METODE PENELITIAN}

Jenis penelitian yang diajukan oleh penulis adalah penelitian dan pengembangan (Research and Development). Menurut Sugiyono (2010: 407) "Metode penelitian dan pengembangan atau dalam bahasa Inggrisnya Research and Development adalah metode penelitian yang digunakan untuk menghasilkan produk tertentu, dan menguji keefektifan produk tersebut".

Dalam penelitian pengembangan ini, peneliti mengacu pada model penelitian dan pengembangan (R\&D) Model ADDIE. "Model rancangan pembelajaran ADDIE merupakan model prosedural yang sederhana dan mudah untuk memproduk bahan ajar, untuk pelatihan jangka pendek atau berkesinambungan" (Hasyim, 2016: 97). Langkah desain ADDIE dapat disesuaikan dengan langkah R\&D dijelaskan pada gambar berikut: 
Tabel 1. Langkah Desain Model ADDIE

\begin{tabular}{|c|c|c|}
\hline Langkah Model & Kegiatan Peneliti & Langkah R\&D \\
\hline Analysis & $\begin{array}{l}\text { Analisis kinerja dan analisis kebutuhan } \\
\text { untuk menentukan masalah dan solusi } \\
\text { yang tepat dan menentukan kompetensi } \\
\text { peserta pelatihan. }\end{array}$ & $\begin{array}{l}\text { Langkah ke } 1 \text { R\&D studi lapangan } \\
\text { dan studi literatur }\end{array}$ \\
\hline Design & $\begin{array}{l}\text { Menentukan kompetensi khusus, metode, } \\
\text { bahan ajar dan strategi pembelajaran. }\end{array}$ & Tahap ke 2 Planning R\&D \\
\hline Development & $\begin{array}{l}\text { Memproduksi program dan bahan ajar } \\
\text { yang akan digunakan dalam pelatihan. }\end{array}$ & $\begin{array}{l}\text { Tahap ke } 3 \text { pengembangan produk } \\
\text { berupa bahan ajar, strategi, media. }\end{array}$ \\
\hline Implementation & $\begin{array}{l}\text { Melaksanakan pelatihan dan menerapkan } \\
\text { desain. }\end{array}$ & $\begin{array}{l}\text { Tahap ke } 4 \text { dan } 6 \text { R\&D uji coba } \\
\text { terbatas dan uji lapangan. }\end{array}$ \\
\hline Evaluation & $\begin{array}{l}\text { Melakukan evaluasi program pelatihan } \\
\text { dan evaluasi hasil belajar. }\end{array}$ & $\begin{array}{l}\text { Tahap ke } 5 \text { dan } 7 \text { evaluasi dan } \\
\text { revisi produk. }\end{array}$ \\
\hline
\end{tabular}

Dalam hal ini penulis memilih jenis penelitian berupa penelitian dan pengembangan (Research and Development) karena penulis mengembangkan produk berupa media pembelajaran. Media pembelajaran ini dikembangkan dengan inovasi yang baru tentunya melalui tahap pengujian terlebih dahulu.

Subyek penelitian adalah seluruh siswa kelas IV SDN 04 Wonokromo. Analisis data yang digunakan dalam penelitian ini yaitu analisis data kualitatif dan analisis data kuantitatif. Data kulitatif dalam penelitian ini yaitu berupa komentar dan saran perbaikan dari ahli media dan ahli materi pembelajaran. Data kuantitatif dalam penelitian ini berupa skor penilaian ahli media, ahli materi, respon guru dan siswa. Kedua data tersebut didapat dari pengisian angket. Data yang sudah terkumpul dianalisis dengan cara menghitung skor yang diperoleh. Analisis skor yang digunakan yaitu analisis deskriptif yang dianalisis menggunakan langkah-langkah sebagai berikut:

Penilaian angket kevalidan

Menganalisis dari lembar angket dengan skala Likert berbentuk Checklist (?) dengan langkah sebagai berikut: (a) Peneliti menghitung skorsing setiap jawaban; (b) Menghitung jumlah skor yang diperoleh dari penelitian; (c) Menjumlahkan skor ideal yang diperoleh untuk seluruh item; (d) Membagi jumlah skor total dengan skor ideal; (e) Kemudian dikali 100\%.

$$
\text { presentase }=\frac{\text { skor } \text { total }}{\text { skor ideal }} \times 100 \%
$$

Dari presentase yang telah diperoleh kemudian ditransformasikan kedalam kalimat yang bersifat kuantitatif. Untuk menentukan kriteria dikemukakan Arikunto (2010: 44):

Tabel 2. Kriteria Skor Dikemukakan Arikunto

\begin{tabular}{lll}
\hline No. & Interval $(\%)$ & Kriteria \\
\hline 1. & $81-100$ & Sangat Baik \\
2. & $61-80$ & Baik \\
3. & $41-60$ & Cukup \\
4. & $21-40$ & Kurang \\
5. & $0-20$ & Kurang Sekali \\
\hline
\end{tabular}

Berdasarkan Tabel 1 dijelaskan bahwa dalam menghitung penilaian angket validitas diperlukan rumus presentase yang kemudian dapat dilihat nilainya melalui interval dan kriteria kualitatif. Apakah media yang dibuat peneliti sangat tidak layak atau sangat layak untuk digunakan.

Penilaian angket kepraktisan

Hasil penilaian respon guru terhadap media pembelajaran Tumblr Light untuk menganalisis data dari lembar angket tanggapan guru dengan skala Likert bentuk checklist (?) dilakukan dengan perhitungan yang sama dengan cara penilaian pada angket kevalidan.Hasil penilaian tanggapan siswa 
terhadap media pembelajaran Tumblr Light dengan skala Guttman yang berupa "Ya-Tidak" diubah menjadi angka, dapat dilihat pada Tabel 3.

Tabel 3. Penskoran Angket Tanggapan Siswa

\begin{tabular}{cc}
\hline Respon Siswa & Skor \\
\hline Ya & 1 \\
Tidak & 0 \\
\hline
\end{tabular}

Data kuantitatif yang terkumpul selanjutnya dianalisis dengan skala likert. Persentase tersebut menunjukkan tingkat keidealan media pembelajaran Tumblr Light berdasarkan penilaian respon guru dan siswa kelas IV SDN 04 Wonokromo.

Berdasarkan penilaian kedua angket tersebut peneliti dikatakan berhasil apabila sesuai dengan indikator yang diharapkan. Dapat dikatakan valid dan praktis apabila presentase dari hasil ahli media dan ahli materi berada pada rentang 61-80\% dengan kriteria "baik".

\section{ANALISIS DAN PEMBAHASAN}

Media pembelajaran Tumblr Light dikembangkan berdasarkan penelitian dan pengembangan (research and development). Penelitian ini menggunakan desain pengembangan model ADDIE yang terdiri dari analisis (analisys), desain (design), penerapan (development), penerapan (implementation), dan evaluasi (evaluation).

1. Analisis

Pada tahap ini menganalisis permasalahan yang ada, ditemukan permasalahan dalam pembelajaran di kelas IV. Permasalahan tersebut adalah siswa belum memahami materi Hubungan Antargaris, kurang aktif dalam bertanya, serta belum tersedianya media pembelajaran yang menarik. Karena guru tidak menggunakan media pembelajaran yang menarik siswa kurang tertarik untuk mengikuti pelajaran sehingga siswa mengalami kesulitan untuk memahami materi.

2. Desain

Berdasarkan studi pendahuluan yang telah dilakukan, maka mengembangkan media pembelajaran yang dapat menarik perhatian siswa untuk belajar. Media yang dikembangkan adalah media Tumblr Light Hubungan Antargaris. Media ini menggunakan lampu yang berwarna-warni yang dipasang secara vertikal dan horisontal pada papan tersebut. Media Tumblr Light Hubungan Antargaris dikembangkan berdasarkan pembelajaran Matematika yang berpedoman pada Kurikulum 2013. Dengan dikembangkannya media pembelajaran tersebut diharapkan peserta didik akan mendapat pengalaman baru serta tertarik untuk mengikuti kegiatan pembelajaran menggunakan media pembelajaran yang berbeda dari biasanya.

3. Pengembangan

a. Pembuatan media Tumblr Light Hubungan Antargaris

Pada tahap pengembangan, peneliti membuat media pembelajaran Tumblr Light Hubungan Antargaris.

b. Validasi ahli media dan materi

Validator atau pakar ahli yang memvalidasi media dan yang memvalidasi materi dalam media Tumblr Light pada kelas IV Sekolah Dasar pada materi Hubungan Antargaris merupakan dosen dari PGSD Universitas PGRI Semarang, yaitu Singgih Adhi Prasetyo, S.Sn.,M.Pd., M. Yusuf Setia Wardhana, S.Pd., M.Pd dan Ervina Eka Subekti, S.Si., M.Pd. Berikut merupakan deskripsi hasil tahap pengembangan yang telah dilakukan oleh peneliti:

1) Penilaian ahli media

Tabel 4. Hasil Validasi Ahli Media

\begin{tabular}{llll}
\hline No. & Ahli Media & Presentasi Keidealan & Kriteria \\
\hline 1 & Singgih Adhi Prasetyo, S.Sn.,M.Pd & $86,25 \%$ & Sangat Baik \\
2 & M. Yusuf Setia Wardhana, S.Pd., M.Pd & $98,75 \%$ & Sangat Baik \\
\hline
\end{tabular}

Berdasarkan Tabel 4 maka dapat diperoleh hasil rata-rata presentase keidealan penilaian ahli media sebesar 92,5\% sehingga media Tumblr Light Hubungan Antargaris termasuk dalam kriteria "sangat baik". Pada validasi ini terdapat saran perbaikan berupa pemberian buku petunjuk 
penggunaan, pemberian pelindung pada lampu bagian vertikal, serta memperbaiki baris pada setiap lampu supaya terlihat lurus.

2) Penilaian Ahli Materi

Tabel 5. Hasil Validasi Ahli Materi

\begin{tabular}{llll}
\hline No. & Ahli Materi & Presentasi Keidealan & Kriteria \\
\hline 1. & Singgih Adhi Prasetyo, S.Sn., M.Pd. & $83,33 \%$ & Sangat Baik \\
2. & M. Yusuf Setia Wardhana, S.Pd., M.Pd. & $96,66 \%$ & Sangat Baik \\
3. & Ervina Eka Subekti, S. Si., M.Pd. & $98,33 \%$ & Sangat Baik \\
\hline
\end{tabular}

Berdasarkan Tabel 5 maka dapat diperoleh hasil rata-rata presentase keidealan penilaian ahli materi sebesar 94,16\% sehingga media Tumblr Light Hubungan Antargaris termasuk dalam kriteria "sangat baik".

c. Hasil Respon Siswa dan Respon Guru

Keberhasilan media yang dikembangkan berdasarkan dilakukannya uji coba lapangan sehingga media pembelajaran Tumblr Light pada materi Hubungan Antargaris dapat diterima dan dikatakan berhasil. Data mengenai respon siswa dan respon guru pada media ini dalam bentuk skala Likert. Uji coba lapangan awal dilakukan peneliti di kelas IV di SDN 04 Wonokromo yang bertujuan untuk mengetahui respon guru kelas dan respon siswa. Sehingga diperoleh hasil sebagai berikut:

1) Hasil Respon Siswa

Tabel 6. Hasil Respon Siswa

\begin{tabular}{llll}
\hline No. & Kelas & Presentasi Keidealan & Kriteria \\
\hline 1. & IV & $95,65 \%$ & Sangat Baik \\
\hline
\end{tabular}

Berdasarkan Tabel 6 menunjukkan bahwa hasil analisis respon siswa terhadap media Tumblr Light Hubungan Antargaris, diperoleh hasil sebesar 95,65\%. Sehingga media Tumblr Light Hubungan Antargaris termasuk dalam kategori "Sangat Baik".

2) Hasil Respon Guru

Tabel 7. Hasil Respon Guru

\begin{tabular}{llll}
\hline No. & Guru & Presentasi Keidealan & Kriteria \\
\hline 1. & Erika Budi Suryani, S.Pd., S.D. & $92 \%$ & Sangat Baik \\
\hline
\end{tabular}

Berdasarkan Tabel 7 menunjukkan bahwa hasil analisis respon guru terhadap media Tumblr Light Hubungan Antargaris yang dilakukan oleh guru kelas IV SDN 04 Vwonokromo yang bernama ibu Erika Budi Suryani, S.Pd. S.D., diperoleh hasil sebesar 92\%. Sehingga media Tumblr Light Hubungan Antargaris termasuk dalam kategori "Sangat Baik”.

\section{KESIMPULAN}

Berdasakan hasil penelitian dan pengembangan media pembelajaran Tumblr Light Hubungan Antargaris dapat disimpulkan bahwa: Dihasilkan produk media pembelajaran Tumblr Light Hubungan Antargaris. Media berbahan papan yang terdapat lampu berwarna-warni yang disusun secara vertikal dan horisontal.

Media Pembelajaran Tumblr Light HubunganAntargaris memiliki hasil nilai rata-rata ahli materi sebesar $94,16 \%$ dan hasil rata-rata ahli media pembelajaran sebesar 92,5\%. Nilai tersebut berdasarkan rekapitulasi hasil penilaian ahli materi dan ahli media pembelajaran. Nilai tersebut berada pada interval 81\%-100\% dan termasuk dalam kriteria "Sangat Baik". Artinya media Tumblr Light Hubungan Antargaris layak digunakan sebagai media pembelajaran pada mata pelajaran Matematika materi Hubungan Antargaris.

Media pembelajaran Tumblr Light Hubungan Antargaris mendapatkan respon dari guru sebesar 92\% yang dihitung berdasarkan angket respon guru dan media pembelajaran Tumblr Light Hubungan 
Antargaris mendapatkan respon dari siswa sebesar 95,65\% yang dihitung berdasarkan angket respon siswa. Kedua nilai tersebut terletak pada interval 81\%-100\% dan termasuk dalam kategori "Sangat Baik". Hal tersebut membuktikan bahwa media Tumblr Light Hubungan Antargaris layak dan dapat diterima dengan baik oleh guru maupun siswa untuk digunakan sebagai media pembelajaran Matematika.

Berdasarkan hasil penelitian yang telah dilakukan, maka saran yang diberikan adalah: Media Tumblr Light Hubungan Antargaris dapat digunakan pada pembelajaran Matematika pada materi Hubungan Antargaris. Dalam kegiatan pembelajaran hendaknya menggunakan media pembelajaran terutama pada materi pembelajaran Matematika yang masih sulit dipahami oleh siswa karena dengan menggunakan media, pembelajaran akan berlangsung lebih menarik dan menyenangkan.

Penelitian dan pengembangan yang belum sempurna ini, diharapkan dilakukan penelitian pengembangan selanjutnya di kemudian hari guna menyempurnakan penelitian ini dan menjadi produk baru dalam penelitian pengembangan tentang media pembelajaran.

\section{DAFTAR PUSTAKA}

Ahmad, Abdul Karim H. 2007. Media Pembelajaran. Makassar: Badan Penerbit Universitas Negeri Makassar.

Agam, Bima Brilliando, Yushardi, dan Prihandono, Trapsilo. 2015. "Pengaruh Jenis dan Bentuk Lampu terhadap Intensitas Pencahayaan dan Energi Buangan melalui Perhitungan Nilai Efikasi Luminus". 3: 384-389.

Arsyad, Azhar. 2016. Media Pembelajaran. Jakarta: PT RAJAGRAFINDO PERSADA.

Fitriyani. 2017. "Pengembangan Media Electric Blood pada Pembelajaran Sistem Peredaran Darah Manusia untuk Siswa Kelas V Sekolah Dasar".

Hasyim, Ardelina. 2016. Metode Penelitian dan Pengembangan di Sekolah. Yogyakarta: Media Akademi.

Jalinus, Nizwardi dan Ambiyar. 2016. Media dan Sumber Pembelajaran. Jakarta: KENCANA.

Munadi, Yudhi. 2013. Media Pembelajaran. Jakarta: REFERENSI (GP Press Group).

Putra, Nusa. 2015. Research \& Development Penelitian dan Pengembangan: Suatu Pengantar. Jakarta: PT Rajagrafindo Persada.

Romadhoni, Mesti Fajar, dan Relmasira, Stefanus C. 2017. "Perbedaan Pengaruh Penerapan Model Pembelajaran Course Review Horay dan Quantum Teaching Dilihat dari Hasil Belajar Matematika Siswa Kelas 3 SD". 1: 93-104.

Soegeng, AY. 2017. Filsafat Pendidikan. Yogyakarta: Magnum Pustaka Utama.

Sugiyono. 2009. Metode Penelitian Kuantitatif Kualitatif dan R\&D. Bandung: ALFABETA, cv.

Sugiyono. 2010. Metode Penelitian Pendidikan Pendekatan Kuantitatif, Kualitatif, dan R\&D. Bandung: ALFABETA, cv.

Sugiyono. 2017. Metode Penelitian Pendidikan. Bandung: Alfabeta.

Sudjana, Nana dan Ahmad Rivai. 2007. Media Pengajaran.Bandung: Sinar Baru Algensindo.

Sukmadinata, Nana Syaodih. 2016. Metode Penelitian Pendidikan. Bandung: PT REMAJA ROSDAKARYA.

Yulianti, Eni. Zulkardi, dan Siroj, Rusdy A. 2010. “Pengembangan Alat Peraga Menggunakan Rangkaian Seri-Pararel untuk Mengajarkan Logika Matematika di SMK Negeri 2 Palembang". 4: 25

Zulkarnain, Aditya Sena. 2016. "Pengembangan Media Komik Semboyan Pahlawan Nasional terhadap Minat Belajar Siswa Kelas 4 SD N Bojongbata 02 Pemalang". Semarang: Pendidikan Guru Sekolah Dasar.

Pranomo, Wisnu Wibowo. 2014. Hubungan Motivasi Belajar Dengan Prestasi Belajar Siswa Kelas X Teknik Pemesinan Di Smk Antartika 1 Sidoarjo. JPTM, Volume 3 Nomor 1, Hal. 114 - 120

Prayitno. 1995. Layanan Bimbingan Dan Konseling Kelompok Dasar Dan Profil. Jakarta: Rineka Cipta 
Prayitno. 2004. Layanan Bimbingan Kelompok Dan Konseling Kelompok. Padang: Universitas Negeri Padang

Sampurnawati, Endang. 2013. Artikel Upaya peningkatan motivasi belajar melalui Bimbingan Kelompok (PTBK pada siswa SMK Perintis 29 Semarang. Jurnal Ilmiah Pendidikan Bimbingan dan Konseling Vol 1, No 2. IKIP Veteran Semarang.

Slameto. 2003. Belajar dan Faktor - faktor yang Mempengaruhinya. Jakarta:Rineka Cipta.

Sugiyono. 2011. Metode Penelitian Administratif. Bandung: Alfabeta.

Sugiyono. 2013. Metode Penelitian Pendidikan Pendekatan Kuantitatif, Kualitatif, dan R\&D. Bandung: Alfabeta.

Sri Susandi Ulandari, Komang. 2014. "Hubungan Antara Motivasi Belajar Dengan Prestasi Belajar Siswa SD Kelas V Semester Ganjil Di Desa Buruan.” Jurnal Mimbar PGSD Universitas Pendidikan Ganesha. Volume 2, Nomor 1 (hlm. 119). Tersedia pada http://pps.unj.ac.id/journal/jpd/ article/view/383 (diakses tanggal 25 Februari 2017).

Winkel, W.S \& Sri Hastuti. 2006. Bimbingan dan Konseling di Institusi Pendidikan. Jakarta: PT. Grasindo.

Winkel.W.S. \& Sri Hastuti. 2010. Bimbingan dan Konseling di Institusi Pendidikan. Jakarta: PT. Grasindo

Winkel. 2012.Psikologi Pengajaran.Yogyakarta : Media Abadi 